\title{
ASUHAN KEPERAWATAN PADA SALAH SATU ANGGOTA KELUARGA DENGAN GANGGUAN MOBILITAS FISIK AKIBAT GOUT ARTRITIS DI WILAYAH KERJA PUSKESMAS TAHUNA BARAT
}

\author{
NURSING CARE OF A FAMILY MEMBER WITH PHYSICAL MOBILITY DISORDER \\ DUE TO GOUT ARTRITIS IN THE WORKING AREA OF PUSKESMAS TAHUNA BARAT
}

\author{
Rinaldi Adrian, Yeanneke Liesbeth Tinungki, Gracia Christy Tooy \\ Program Studi Keperawatan, Politeknik Negeri Nusa Utara \\ Email: yeanneketinungki82@gmail.com
}

\begin{abstract}
Abstrak : Gout Artritis merupakan salah satu penyakit yang telah lama dikenal dan sampai saat ini masih menjadi penyebab berbagai penyakit. Prevalensi gout artritis menurut World Health Organization (WHO) tahun 2018 gout artritis mengalami kenaikan dengan jumlah $1.370(33,3 \%)$. Gangguan mobilitas fisik ini sering menjadi masalah keperawatan pada kasus Gout Artritis akibat kadar purin tinggi dalam darah, maka tubuh akan meresponnya dengan ditandai adanya hambatan mobilitas fisik pada sendi, menggigil dan badan lemah. Tujuan studi kasus diketahuinya asuhan keperawatan pada salah satu keluarga dengan gangguan mobilitas fisik akibat gout artritis di wilayah kerja Puskesmas Tahuna Barat. Metode studi kasus adalah desain studi kasus deskriptif dengan subjek studi kasus satu orang klien yang diamati dan berfokus untuk mengajarkan latihan rentang gerak (ROM) dan melibatkan keluarga untuk membantu klien dalam meningkatkan pergerakan. Hasil yang diperoleh : Diagnosa keperawatan gangguan mobilitas fisik berhubungan dengan ketidakmampuan keluarga dalam merawat anggota keluarga yang sakit, subjek studi kasus ditemukan nyeri pada lutut dan keluarga tidak tahu perawatan yang dibutuhkan untuk menanggulangi masalah kesehatan atau penyakit yang dialami yang menyebabkan gangguan mobilitas fisik. Kesimpulan : Masalah pada klien teratasi karena klien sudah dapat bergerak walaupun nyeri hilang dan sudah dapat melakukan mobilisasi dini dengan adanya dukungan keluarga. Saran : Perawat lebih meningkatkan pelayanan serta dapat memberikan pendidikan kesehatan pada klien yang menderita gout artritis.
\end{abstract}

Kata Kunci : Gangguan Mobilitas Fisik, Keluarga, Gout Artritis

\begin{abstract}
Gout artritis is a disease that has been known for a long time and is still the cause of various diseases. The prevalence of gout artritis to the World Health Organization (WHO) in 2018 gout artritis has increased by 1370 (33,3\%). Impaired physical mobility was often a nursing problem in cases of Gout artritis due to high levels of purines in the body's blood which responds to it by being marked by obstacles to physical mobility in the joints, chills and weakness. The purpose of the case study was to find out nursing care in a family with impaired physical mobility due to gout artritis in the work area Puskesmas of the Tahuna Barat. The case study method was a descriptive case study design with a case study subject of one client who was observed and focus on teaching range of motion (ROM) exercise and involve the family to assist the client in improving movement. The result obtained: Nursing diagnosis of impaired physical mobility related to the inability of the family to care of sick family members, case study subjects found knee pain and the family who did not know the treatment needed to overcome health problem or illnesses that caused physical mobility problems. Conclusion: The Problem in the client was resolved because the client was able to move even though the pain was gone and can do early mobilization with family support. Suggestion: Nurse improve services and can provide health education to client who suffering from gout artritis.
\end{abstract}

Keyword: Physical Mobility Disorder, Family, Gout artritis 


\section{PENDAHULUAN}

Gout Artritis merupakan salah satu penyakit yang telah lama dikenal dan sampai saat ini masih menjadi penyebab berbagai penyakit (Riskesdas, 2013). Gout artritis merupakan salah satu penyakit inflamasi sendi yang paling sering ditemukan, ditandai dengan penumpukan kristal monosodium urat di dalam ataupun di sekitar persendian (Zahara, 2013). Serangan gout artritis sering kali dapat menyebabkan kerusakan struktural yang berlanjut pada pembentukan tofi, sehingga dapat menimbulkan kerusakan sendi dan kehilangan fungsinya. Kecacatan akibat gout artritis serta masalah penampilan pada pasien. Pada gout kronis, timbul benjolan (tofus). Biasanya, terdapat pada daun telinga, ujung siku, lutut, serta punggung tangan dan kaki. (Kusuma, 2018).

Prevalensi gout artritis menurut World Health Organization (WHO) tahun 2018 dalam Ndede (2019) gout artritis mengalami kenaikan dengan jumlah 1370 (33,3\%). Di Inggris dan Amerika penderita gout artritis pada orang dewasa juga mengalami peningkatan, di Inggris sebanyak 3,2\% dan Amerika sebanyak 3,9\%. Angka prevalensi penyakit gout artritis bervariasi pada negara negara barat, dan Indonesia menempati peringkat pertama di Asia Tenggara (Kuo, 2015 dalam Ndede, 2019).

Data Kementrian Kesehatan RI tahun 2018 menunjukan prevalensi gout artritis di Indonesia berdasarkan diagnosis pada penduduk usia di atas 15 tahun sebanyak 7,3\%. Pada jenis kelamin laki-laki $6.1 \%$ sedangkan pada perempuan $8.5 \%$. Sulawesi utara prevalensi gout artritis sebanyak 7,5\%. Data yang didapat dari Puskesmas Tahuna Barat kira-kira terdapat 5 orang yang menderita gout artritis setiap bulan dan Puskesmas Tahuna Barat belum melakukan pendataan secara akurat mengenai penyakit gout artritis karena penderita gout artritis sangat minim di wilayah kerja Puskesmas Tahuna Barat (Profil Puskesmas Tahuna Barat 2019). Gangguan mobilitas fisik ini sering menjadi masalah keperawatan pada kasus gout artritis akibat tingginya kadar purin didalam darah, maka tubuh akan meresponnya dengan ditandai adanya hambatan mobilitas fisik pada sendi, menggigil dan badan lemah (Helmi, 2012). Jika hal tersebut terus dibiarkan karena keluarga tidak mampu merawat anggota keluarga yang menderita gout artritis maka akan menyebabkan komplikasi yang berbahaya, seperti persendian menjadi rusak bahkan sampai kecacatan, untuk itu diperlukan dukungan keluarga dan pemahaman keluarga untuk mengatasi kekakuan sendi seperti latihan rentang gerak/ROM. Berdasarkan uraian di atas peneliti tertarik untuk menerapkan "Asuhan keperawatan pada salah satu anggota keluarga dengan gangguan mobilitas fisik akibat gout artritis" di wilayah kerja Puskesmas Tahuna Timur.

\section{METODE PENELITIAN}

Penelitian ini menggunakan rancangan studi kasus dengan pendekatan proses asuhan keperawatan. Subjek studi kasus yaitu 1 orang klien gout artritis yang mengalami gangguan mobilitas fisik. Pemilihan subjek studi kasus didasarkan pada anggota keluarga yang mengalami kekambuhan saat penelitian dan anggota keluarga menderita gout artritis tanpa komplikasi penyakit lain serta anggota keluarga yang tidak bisa beraktivitas karena nyeri.

Fokus studi kasus yaitu gangguan mobilitas fisik pada keluarga akibat gout arthritis. Instrumen penelitian adalah pengkajian keluarga. 


\section{HASIL DAN PEMBAHASAN}

Hasil pengkajian didapatkan klien Tn. J.M berusia 59 tahun, beragama kristen, bertempat tinggal di kelurahan Kolongan Akembawi RT.01 dan sudah tidak bekerja. Selama klien sakit yang dekat dan bertanggung jawab pada klien adalah $\mathrm{Ny}$. B.M yang bekerja sebagai IRT, hubungan dengan klien adalah istri dan tinggal serumah. Pada saat dikaji Tn. J.M mengatakan sulit bergerak, nyeri kedua lutut dan nyeri bertambah saat melakukan aktivitas, nyeri seperti ditusuk-tusuk, skala nyeri 4-5 dan Tn J.M mengatakan kalau tambah nyeri dia lebih memilih berbaring di tempat tidur serta menggunakan tongkat saat melakukan aktivitas. Ny B.M tidak tahu perawatan yang dibutuhkan untuk menanggulangi masalah kesehatan atau penyakit yang diderita Tn. J.M selain memberi obat jika penyakit suaminya kambuh dan beristirahat di tempat tidur serta membatasi aktivitas. Saat dilakukan pemeriksaan tanda-tanda vital TD 140/90 $\mathrm{mmHg}, \quad \mathrm{N} \quad 80 \mathrm{X} / \mathrm{m}, \quad \mathrm{R} 20 \mathrm{X} / \mathrm{m}$ dan dilakukan pemeriksaan kadar asam urat dengan hasil pemeriksaan 13,1 dl/gr. Pengkajian aktivitas dan latihan didapatkan klien mengatakan nyeri saat beraktivitas, skala nyeri 4-5 dan skala aktivitas klien memerlukan bantuan dan pengawasan orang lain (tingkat 2).

Diagnosa keperawatan adalah gangguan mobilitas fisik berhubungan dengan ketidakmampuan keluarga merawat anggota keluarga yang sakit. Intervensi keperawatan meliputi tindakan observasi yaitu 1) Identifikasi adanya nyeri atau keluhan fisik lainnya; 2) Identifikasi toleransi fisik melakukan pergerakan; 3) Monitor frekuensi jantung dan tekanan darah sebelum memulai mobilisasi; 4) Monitor kondisi umum selama melakukan mobilisasi. Tindakan Terapeutik meliputi
1) Fasilitasi aktivitas mobilisasi dengan alat bantu (mis pagar tempat tidur), 2) Fasilitasi melakukan pergerakan,jika perlu, 3) Libatkan keluarga untuk membantu pasien dalam meningkatkan pergerakan. Tindakan Edukasi meliputi 1) Jelaskan tujuan dan prosedur mobilisasi, 2) Anjurkan melakukan mobilisasi dini, 3) Ajarkan mobilisasi sederhana yg harus dilakukan (mis. Duduk ditempat tidur, dll).

Tujuan yang diharapkan setelah dilakukan tindakan keperawatan selama 3 hari mobilitas fisik meningkat dengan kriteria hasil :1) Pergerakan ekstremitas 5 (meningkat), 2) Kekuatan otot 5 (menigkat), 3) Rentang gerak (ROM) 5 (meningkat), 4) Nyeri 5 (menurun) 5) Kecemasan 5 (menurun), 6) Kaku sendi 5 (menurun) 7) Gerakan tidak terkoordinasi 5 (menurun), 8) Kelemahan fisik 5 (menurun).

Implementasi yang dilakukan berdasarkan intervensi selama kurang lebih 3 hari semua intervensi sudah dapat dilaksanakan dengan cukup baik untuk membantu melatih rentang gerak pada pasien yang mengalami gangguan mobilias fisik. Implementasi keperawatan hari pertama melakukan tindakan melakukan pemeriksaan kadar asam urat, mengobservasi toleransi fisik selama melakukan pergerakan, mengobservassi kondisi umum klien selama melakukan mobilisasi, menjelaskan tujuan dan prosedur mobilisasi kepada Tn J.M dan istrinya Ny. B.M, mengajarkan Mobiliasi sederhana kepda Tn J.M atau melatih rentang gerak (ROM). Implementasi hari kedua tindakan keperawatan menjadi 3 intervensi dan mengubah satu intervensi yaitu Melibatkan keluarga untuk membantu pasien dalam meningkatkan pergerakan. Implementasi keperawatan hari ketiga melakukan tindakan keperawatan dengan 3 intervensi yang tetap melibatkan keluarga, menganjurkan klien mobilisasi

\section{POLITEKNIK NEGERI NUSA UTARA}


secara dini secara mandiri dan tetap melatih rentang gerak.

Pengkajian adalah tahapan seorang perawat mengumpulkan inormasi secara terus menerus terhadap anggota keluarga yang dibinannya (Mubarak, 2012). Pengkajian ini merupakan tahap awal untuk penerapan asuhan keperawatan pada subjek studi kasus yang mengalami gangguan mobilitas fisik akibat gout artritis.

Hasil dari pengkajian pada klien didapatkan klien mengeluh sulit bergerak, nyeri lutut dan bertambah saat melakukan aktivitas serta didapatkan ketidakmampuan istri mengambil keputusan untuk menanggulangi masalah kesehatan. Dan dari pengkajian dilakukan pemeriksaan kadar asam urat $13,1 \mathrm{dl} / \mathrm{gr}$ dan tampak bengkak.

Berdasarkan data yang diperoleh melalui pengkajian dari subjek studi kasus yang berlokasi di Puskesmas Tahuna Barat, maka dari hasil penelitian tersebut peneliti mengangkat diagnosis keperawatan gangguan mobilitas fisik berhubungan dengan ketidakmampuan keluarga merawat anggota keluarga yang sakit. Gangguan mobilitas fisik didefenisikan oleh Persatuan Perawat Nasional Indonesia (PPNI, 2016) keterbatasan dalam gerakan fisik dari satu atau lebih ekstremitas secara mandiri yang ditandai dengan mengeluh sulit mengerakan ekstremitas, nyeri saat bergerak, gerakan terbatas dan fisik lemah.

Intervensi keperawatan adalah dimana perawat menyusun rencana tindakan yang akan dilakukan, dan rencana tindakan ini harus sesuai dengan dianosa keperawatan yang diangkat (Febrianti, 2019). Maka berdasarkan diagnosa yang diangkat peneliti menyusun rencana atau melakukan tindakan keperawatan kurang lebih selama 3 hari kepada klien seperti yang sudah ditulis sebelumnnya.

Tahapan Implementasi adalah pada tahap ini peneliti melaksanakan tindakan keperawatan yang sudah disusun sebelumnya, dan tahap ini merupakan tahap lanjutan yang bertujuan untuk mengajarakn tindakan yang sudah direncanakan seperti mengajarakan klien untuk latihan rentang gerak (ROM) dan menganjurkan pasien untuk mobilisasi dini secara mandiri dan tindakan selanjutnya itu tetap dilakukan seperti yang ditulis peneliti sebelumnya (Nopindrawati, 2018).

Tahapan Evaluasi menurut Mubarak (2012), evaluasi proses keperawatan ada dua yaitu evaluasi kuantitatif dan evaluasi kualitatif. Evaluasi ini merupakan bagian tahap paling akhir dari 5 langkah proses asuhan keperawatan. Tahap evaluasi ini dilakukan pada hari rabu 25 maret 2020 jam 09.00 dengan hasil klien sudah dapat bergerak walaupun nyeri hilang timbul dengan skala nyeri 3 dan sudah dapat mempraktekan secara mandiri sehingga masalah ini dapat dikatakan masalah teratasi.

\section{KESIMPULAN}

Kesimpulan penelitian ini adalah asuhan keperawatan mulai pengkajian subjek studi kasus ditemukan nyeri pada lutut dan keluarga tidak tahu perawatan yang dibutuhkan untuk menanggulangi masalah kesehatan atau penyakit yang dialami menyebabkan gangguan mobilitas fisik. Diagnosis Keperawatan adalah gangguan mobilitas fisik yang berhubungan dengan ketidakmampuan keluarga merawat anggota keluarga yang sakit. Intervensi berfokus untuk mengajarkan latihan rentang gerak dan melibatkan keluarga untuk membantu pergerakan. Implementasi keperawatan dilakukan sesuai dengan intervensi yang telah disusun. Evaluasi dilakukan peneliti pada subjek studi kasus Tn J.M 
dilakukan pada hari 3 dengan masalah teratasi.

\section{DAFTAR RUJUKAN}

Febrianti, R. (2019). Asuhan Keperawatan Keluarga Dengan Gout arthritis Di Wilayah Kerja Puskesmas Juanda Samarinda. Kaltim: Skripsi D-III keperawatan Poltekes Kemenkes Kaltim.

Helmi, Z. N. (2012). Buku Ajar Gangguan Muskuloskeletal. Jakarta: Salemba Medika.

Kementrian Kesehatan RI (2018). Riset Kesehatan Dasar. Jakarta : Badan Penelitian dan Pembangunan Kesehatan Kementrian RI.

Kusuma, I. (2018). Asuhan Keperawatan Dengan Masalah Hambatan Mobilitas Fisik Pada Pasien Gout Artritis Dipanti Werdha Mojopahit Mojokerto.

Mubarak, Wahid, I. (2012). Ilmu Keperawatn Komunitas 2 : Konsep dan Aplikasi. Jakarta: Salemba Medika.
Nopindrawati, Ni Putu (2018) Gambaran Asuhan Keperawatan Pada Lansia Hipertensi Dengan Nyeri Akut Di UPT Kesmas Sukawati 1 Gianyar Tahun 2018. Diploma thesis, Jurusan Keperawatan, Poltekes Denpasar.

Ndede, V. Z., Oroh, W., \& Bidjuni, H. (2019). Pengaruh Pemberian Rebusan Daun Salam Terhadap Penurunan Kadar Asam Urat Pada Penderita Gout Artritis Di Wilayah kerja Puskesmas Ranotana Weru. e-journal Keperawatan (e-Kp) Volume 7Nomor 1, Februari 2019, 1-8.

PPNI (2016). Standar Diagnosis Keperawatan Indonesia Defenisi dan Indikator Diagnostik. Jakarta: PPNI.

Profil Puskesmas Tahuna Barat, 2019

Zahara, Ali, H. . (2013). Pengantar Keperawatan Keluarga. Jakarta: Buku Kedokteran EGC. 